observaciones directas hechas por un espíritu agudo, observador y dolorido frente al espectáculo del hombre en su escenario isleño, con un hermoso capítulo titulado "El buque de arte", en el que el autor resume admirablemente una de las más antiguas y arraigadas supersticiones de los chilotes: "El Caleuche".

Y al leer la última página de "Gente en la Isla", quedan con nosotros sus personajes inolvidables, como si los hubiéramos conocido y hubiéramos transitado juntos por la vida: Lorenzo Andrada, el usurero Remigio Cárdenas, Adelaida, la infiel, la india Juana, el vasco Urrustarrazu, el cura don Braulio y ese otro personaje magnífico, potente, grandioso y de profundas resonancias que permanece siempre presente a través de la novela: el escenario de la isla con sus barrancos abruptos, sus bosques vírgenes, sus abras profundas, sus tranquilas ensenadas, sus caminos delgados como hilos serpenteantes y el embrujo de sus canales infinitos.

"Gente en la Isla" es, en suma, un libro merecedor de agotarse en sucesivas ediciones y requerido y gustado por todos los públicos del continente. Tiene los méritos suficientes para ello y coloca a su autor entre los grandes novelistas americanos.-Gonzalo Drago.

\title{
DANIEL BELMAR Y RICARDO GUIRALDES
}

En un número ya muy anterior del Boletín del Instituto Amigos del Libro Argentino, Pedro Ortiz Barili dice: "ese Güiraldes chileno que es el autor de Coirón"; ello abrió mi curiosidad y me proponía pedir noticias sobre el novelista cuando el correo puso en mis manos, con unas líneas cordialísimas, la obra de Daniel Belmar. Son doscientas páginas de apretados renglones que he leído de un tirón en este plúmbeo sábado otoñal. Pocas jornadas de tan óptima cosecha. Comprendo el acercamiento que establece Ortiz Barili y el que ensaya Mariano Latorre en la carta-prólogo de Coirón: “...tiene algo del Don 
Segundo Sombra, de Güiraldes, pero con una radical diferenciación. Don Segundo es el gaucho desaparecido, la evocación heroica de un pasado ya muerto, mientras don Leandro de Coirón es un contemporáneo, un chileno del sur, llegado al Neuquén y pleno de porvenir". (Aquí, sin quererlo, Latorre establece la anacronía entre el presunto protagonista de carne y hueso de Güiraldes - Segundo Ramírez, paisano contemporáneo a quien el novelista enarboló y flamearon luego hasta el cansancio sus turiferarios- y la estampa diferenciada del resero literario del libro).

Y prosigue: "Don Leandro también es arriero o rescro, empleando el término gauchesco, como Don Segundo Sombra, pero no es una sombra sino una realidad"; con lo que vuelve a herir el talón de Aquiles güiraldino. Es significativo que también del otro lado de los Andes un escritor señale como axioma notorio, ya que menciona sólo de paso nuestro zangoloteado problema, la irrealidad de su héroe.

Coirón es un enfoque preciso de la realidad en sus ámbitos geográfico y humano, y ello supone un mérito fundamental. Ortiz Barili llama "Güiraldes chileno" a Belmar estableciendo una ecuación lógica si damos por superlativos los valores del arequense; pero Belmar es otra cosa, Belmar es un novelista nato - lo que no es Güiraldes- y un escritor recio, que tampoco es el autor de Raucho. En Coirón vivimos el campo. En Don Segundo Sombra contemplamos una película cinematográfica. En el libro de Belmar se mueven seres humanos que trabajan, sufren, comen, beben, aman, odian, mueren y matan. En el de Güiraldes sólo se nos muestran entelequias flotando en un ambiente ideal. Belmar es un escritor que nos conmueve. Güiraldes es un literato que nos entretiene encantadoramente; pero que sobre todo es eso: un literato.

Don Leandro - figura eje de Coirón- casi no aparece en el libro y está, sin embargo, en todas sus páginas por una poderosa gravitación personal. Es un hombre verdadero, lo dice Latorre: “...un colonizador, un forjador de civilización. Y a su alrededor, rodeada de suavidad y de abnegación, la madre, el vigor viril de los hijos y el de los pastores $y$ arrieros que comparten la dureza de esa vida". 
Nada de esto - así humano- podría acreditarse a la obra güiraldina, porque mientras Don Leandro existe, Don Segundo Sombra es una fabulación. Tampoco en lo poético, en lo descriptivo, en lo literario este escritor de raza que es Belmar tendría por qué ceder medio rollo de lazo ante Güiraldes. Su pintura de costumbres y tipos, el colorido, las imágenes, la síntesis expresiva, el exacto sentido de la medida son admirables. Se podrían citar, como hace el prologuista, episodios ejemplares, pero es que yo creo a todos los episodios igualmente ejemplares y sería cosa de reproducir el libro, que es un todo indiviso: escenario, acción, actores.

Para mí, el descubrimiento de Coirón es un hallazgo felicísimo. Aparear a su autor con Ricardo Güiraldes me parece muy bien en la sana intención de Ortiz Barili - y aun de Mariano Latorre-, sin embargo, atento a mi concepto de los valores, creo que la oración debiera revertirse y reconociendo los innegables valores de Don Segundo Sombra, señalar a Güiraldes como "ese Daniel Belmar arequense", con lo que las letras argentinas y nuestro lógico y natural patriotismo nada sufriría, pues el escritor "chileno" Daniel Belmar es sencillamente argentino, nacido en el Neuquén nuestro, que tan acertadamente pinta en su obra.-Aristóbulo Echegaray. 